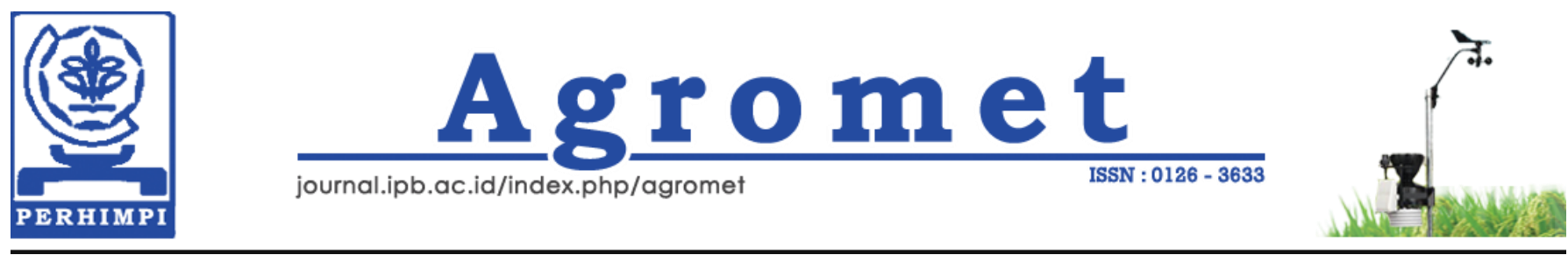

\title{
Kenyamanan Iklim Lokasi Wisata Berbasis Alam di Kawasan Tropis
}

Climate Comfort in Nature-Based Tourism at Tropical Region

\author{
Nofi Yendri Sudiar ${ }^{1,2}$, Yonny Koesmaryono ${ }^{3}$, Perdinan $^{3}$, dan Hadi Susilo Arifin ${ }^{4}$ \\ ${ }^{1}$ Sekolah Pascasarjana IPB, Kampus IPB Dramaga, Bogor 16680 \\ 2Program Studi Fisika, Universitas Negeri Padang, Kampus FMIPA UNP, Padang 25131 \\ ${ }^{3}$ Departemen Geofisika dan Meteorologi, Gedung FMIPA, IPB, Jl. Meranti Wing 19 Lv.4 Kampus IPB Darmaga, Bogor 16680 \\ ${ }^{4}$ Departemen Arsitektur Lanskap, Gedung Fakultas Pertanian IPB, Kampus IPB Darmaga, Bogor 16680
}

\author{
ARTICLE INFO

\section{Article history:} \\ Received 5 September 2019 \\ Received in revised from 26 November \\ 2019 \\ Accepted 18 December 2019
}

doi: 10.29244/j.agromet.33.2.53-61

\section{Keywords:}

Holiday Climate Index

Nature-based tourism

Perception

Thermal comfort

Tourism Climate Index

\begin{abstract}
A B S T R A C T
This research reveals visitor perceptions of climate comfort in nature-based tourism areas in Indonesia. We combined a survey and modeling to calculate the comfort score based on Tourism Climate Index (TCI) and Holiday Climate Index (HCI) in three tourism sites of Ecopark Ancol, Bogor Botanical Garden, and Cibodas Botanical Garden. During the survey, we collected data on climate comfort perceptions and the role of the weather on the comfort. Totally, 793 respondents of tourism visitors participated in the study. Our results showed that almost all of visitors (>95\%) stated that the weather affected the climate comfort. Interestingly, the weather condition did not influence on the decisions where the tourism site to visit. The level of perceived climate comfort for the sites were neutral (Ecopark, 57.3\%), and comfortable (Bogor Botanical Garden, 60\%; Cibodas Botanical Garden, 78.4\%). Then by modeling we obtained the best method to calculate the comfort based on the following index: (i) TCI with Physiological Equivalent Temperature (PET) Tianjin for Ecopark (57.2), (ii) HCI for Bogor Botanical Garden (59), and (iii) HCI with PET Tianjin for Cibodas Botanical Garden (77.6). Further, perception on climate comfort was significantly difference among sex, age, and education level of the visitors. In warmer environmental condition, the older people and women feel more comfortable. Our finding revealed that topography was weak correlated with comfort perception. By understanding visitor perceptions, strategies and appropriate actions can be developed to increase comfort in the nature-based tourism industry.
\end{abstract}

\section{PENDAHULUAN}

Pariwisata telah menjadi industri penting di seluruh dunia termasuk di Indonesia. Perkembangan industri pariwisata di Indonesia cukup signifikan yang menyumbang devisa urutan kelima setelah migas, batu bara, minyak kelapa sawit dan karet olahan pada tahun 2011 (Kemenpar, 2018). Pada tahun 2016, perolehan dari sektor pariwisata menempati urutan kedua setelah kelapa sawit dengan peningkatan devisa sebesar $11 \%$ (US\$ 13,568 miliar). Berdasarkan tren tersebut, diperkirakan sektor pariwisata dapat menjadi penyumbang devisa peringkat pertama di Indonesia pada tahun 2020 .
Industri pariwisata sangat sensitif terhadap cuaca dan iklim (Li et al., 2016; Roshan et al., 2016) karena ini menentukan kemana tujuan wisatawan dalam memilih tempat berwisata. Cuaca dan iklim adalah faktor eksternal penting yang mempengaruhi keputusan untuk menentukan daerah yang akan dikunjungi (Priego et al., 2015; Rutty and Scott, 2016). Berdasarkan informasi tersebut, kondisi iklim dan cuaca menjadi salah satu hal yang penting untuk kegiatan pariwisata. Kenyamanan berwisata mempengaruhi wisatawan dalam menentukan destinasi wisata. Perubahan kondisi iklim suatu daerah dapat berimplikasi negatif pada ketidaknyamanan dan mungkin mengurangi kualitas pengalaman rekreasi (De Urioste-Stone et al., 2015; Scott et al., 2019).

\footnotetext{
*Corresponding author. perdinan@gmail.com
} 
Penelitian mengenai hubungan antara iklim dan kenyamanan dalam berwisata sangat menarik untuk dilakukan, terutama di Indonesia. Kajian tentang tingkat kenyamanan wisata mengunakan variabel iklim pertama kali dikembangkan oleh Mieczkowski, yaitu Tourism Climate Index (TCI) (Fang and Yin, 2015; Mieczkowski, 1985; Noome and Fitchett, 2019). Terdapat lima parameter cuaca yang digunakan dalam perhitungan indeks, yaitu suhu udara, curah hujan, kelembaban, kecepatan angin dan penyinaran matahari. Indeks ini dapat merepresentasikan kondisi selama 24 jam. Akan tetapi, terdapat beberapa kelemahan dari penggunaan TCI, yaitu (i) tidak memasukkan komponen flux radiasi gelombang panjang dan gelombang pendek, (ii) penilaian yang subjektif, (iii) sistem pembobotan variabel iklim, dan (iv) resolusi data yang rendah yakni menggunakan data bulanan (Scott et al., 2016).

Metode baru dikembangkan oleh Scott et al. (2016) yaitu Holiday Climate Index (HCI) untuk mengatasi kekurangan dan keterbatasan dari indeks iklim-pariwisata TCI. Kelebihan HCI dibandingkan dengan TCI terletak pada skala peringkat tiap komponen iklim dan bobot dari setiap parameter. Selain indeks kenyamanan iklim, juga terdapat indeks kenyamanan termal. Indeks kenyamanan termal hanya mempertimbangkan faktor termal tanpa memasukan faktor astetik dan fisik. Beberapa indeks kenyamanan termal, antara lain Predicted Mean Vote (PMV) (Gilani et al., 2015), Physiological Equivalent Temperature (PET) (Lai et al., 2016), Standard Effective Temperature (SET) (Nazarian et al., 2017), dan Universal Thermal Climate Index (UTCI) (Di Napoli et al., 2018). Di Indonesia, penelitian terkait kenyamanan iklim untuk lokasi wisata tertentu menggunakan TCI dan HCI masih sangat terbatas. Sampai saat ini, hanya Haryadi et al., (2019) yang baru menggunakan TCI untuk menghitung indeks kenyamanan iklim di wilayah Indonesia, yaitu di Kabupaten Samosir, Sumatera Utara. Sedangkan untuk HCI, Noor et al. (2018) menggunakan indeks tersebut untuk mengidentifikasi tingkat kenyamanan wisata untuk wilayah Banjarmasin, Kalimantan Selatan.

Secara umum, Penelitian ini bertujuan memberikan pemahaman mengenai persepsi kenyamanan iklim di kawasan wisata yang berbasis alam. Secara khusus, penelitian ini bertujuan untuk mendapatkan informasi: (i) cuaca yang berpengaruh terhadap kenyamanan selama berwisata, (ii) kisaran persepsi tingkat kenyamanan yang dirasakan pengunjung berdasarkan parameter cuaca pada tiga kawasan wisata dengan topografi yang berbeda, dan (iii) perbedaan persepsi pengunjung terhadap kenyamanan iklim saat berwisata.

\section{METODE PENELITIAN}

\section{Lokasi Penelitian}

Pada penelitian ini, kami memilih kawasan wisata pada zona iklim tropis yang terletak pada zona ketinggian tempat berbeda. Lokasi pertama adalah Ecopark Ancol yang berada di kawasan pantai dengan ketinggian 3 mdpl. Lokasi kedua adalah Kebun Raya Bogor yang berada di tengah kota Bogor dengan ketinggian lokasi sekitar dari 215-260 mdpl. Lokasi Ancol dan Kebun Raya Bogor mewakili zona dataran rendah, dengan spesifikasi pantai dan non-pantai. Lokasi ketiga adalah Kebun Raya Cibodas yang terletak di kawasan lereng Gunung Gede-Pangrango dengan ketinggian bervariasi dari 1300-1425 mdpl mewakili dataran tinggi.

\section{Disain Penelitian dan Analisis Data}

Penelitian ini menggunakan metode surveywawancara mengenai kenyamanan termal, atau faktor cuaca dalam mempertimbangkan kunjungan, tingkat kenyamanan yang dirasakan kepada pengunjung. Semua pertanyaan survei diletakkan dalam sebuah aplikasi android dengan nama My Trip My Holidayyang dibuat dengan bahasa Java. Aplikasi ini dirancang untuk memudahkan pengunjung dalam mengisi kuisioner. Dengan aplikasi ini memudahkan dalam mengelola data survei dan perhitungan secara statistik. Untuk pengelolaan data survei tersebut juga dibuat web menggunakan bahasa program populer yakni PHP: Hypertext Prepocessor dengan basis data menggunakan MySQL. Survei dilakukan pada musim pancaroba April dan Mei 2018 dimana pada masa ini terjadi peralihan dari musim hujan ke musim kemarau.

Sebanyak 793 pengunjung (219 orang di Ecopark, 284 orang di KRB dan 290 orang di KRC) sebagai responden dalam penelitian ini dengan tingkat kepercayaan $95 \%$ dan 3,5\% margin of error. Penentuan responden dilakukan dengan cara simple random sampling yaitu sampel yang diambil secara acak sederhana. Pengambilan sampel dilakukan di dalam dan di luar kawasan wisata, yang meliputi (i) lapangan parkir, (ii) sekitar pepohonan, (iii) perdu, (iv) semak, (v) lapangan rumput, (vi) kolam/wisata air, (vii) jalur pejalan kaki, (viii) jalan utama, dan (ix) rest area (saung/gazebo/bangku taman).

Untuk mengukur tingkat kenyamanan iklim pengunjung di setiap lokasi, kami menggunakan TCI dan HCI. Perhitungan TCI dilakukan menggunakan Persamaan (1).

$$
\mathrm{TCI}=8 \mathrm{CID}+2 \mathrm{CIA}+4 \mathrm{P}+4 \mathrm{~S}+2 \mathrm{~W}
$$

dimana CID indeks kenyamanan siang hari, CIA indek kenyamanan harian, $P$ curah hujan $(\mathrm{mm}), \quad S$ lama 
penyinaran (jam), dan $W$ kecepatan angin $(\mathrm{km} / \mathrm{jam})$. Perhitungan indeks HCI dilakukan dengan sistem peringkat terlebih dahulu untuk tiap variabel sebelum dijumlahkan. Rumus perhitungan $\mathrm{HCI}$ untuk lokasi urban-Kebun Raya (Persamaan 2) berbeda dengan lokasi pesisir pantai-Ecopark Ancol (Persamaan 3).

$$
\begin{aligned}
& \mathrm{HCI} \text { urban }=4 \mathrm{TC}+2 \mathrm{~A}+3 \mathrm{P}+\mathrm{W} \\
& \mathrm{HCI} \text { beach }=3 \mathrm{TC}+3.5 \mathrm{~A}+2.5 \mathrm{P}+\mathrm{W}
\end{aligned}
$$

dimana TC kenyamanan termal dengan parameter cuacanya suhu dan kelembaban udara, $A$ faktor astetik dengan parameter cuacanya tutupan awan.

Pada penelitian ini, kami melakukan modifikasi termal dalam perhitungan indeks kenyamanan iklim menggunakan TCI dan HCI. Berdasarkan metode modifikasi aspek termal dari Lai et al. (2014), kami memodifikasi menjadi tujuh aspek termal berdasarkan Physiological Equivalent Temperature (PET) dan Universal Thermal Climate Index (UTCI), yaitu PET Eropa PET Taiwan, PET Tianjin, PET Tel Aviv, UTCI Mediterania, UTCI Tianjin dan UTCI. Aspek termal digunakan untuk memprediksi nilai rata-rata dari sensasi termal berdasarkan: (i) empat parameter cuaca, yaitu suhu, kelembaban udara, angin, dan sinar matahari; dan (ii) dua parameter non cuaca, meliputi metabolisme tubuh dan pakaian yang dikenakan responden.

Pada penelitian ini, kami melakukan identifikasi sejumlah parameter cuaca dan non-cuaca tersebut terhadap responden di lokasi wisata yang berkaitan dengan kenyaman. Untuk indikator metabolisme, kami menggunakan informasi usia, jenis kelamin, dan tingkat pendidikan tiap responden sebagai data acuan. Kemudian, indeks kenyamanan termal dari hasil perhitungan dibandingkan dengan hasil survei persepsi kenyamanan dari pengunjung untuk mengidentifikasi modifikasi yang paling sesuai diterapkan di tiap lokasi wisata.

Untuk mengetahui perbedaan persepsi pengunjung terhadap kenyamanan iklim, kami melakukan analisis statistik menggunakan model regresi logistik biner. Langkah yang kami lakukan meliputi: (i) Melakukan analisis data dengan statistik deskriptif untuk setiap parameter cuaca (suhu udara, kelembaban udara, angin, dan sinar matahari) terhadap usia, jenis kelamin dan tingkat pendidikan. (ii) Membuat konstruksi variabel respon kategorik untuk setiap variabel iklim. Variabel respon $y$ terdiri dari 2 kategori yakni nyaman dan tidak nyaman yang dinotasikan dengan angka 1 (nyaman) dan 0 (tidak nyaman). Responden yang memberi jawaban sangat tidak nyaman, tidak nyaman dan netral akan dikategorikan $y$ $=0$ (tidak nyaman) dan responden yang memberi jawaban nyaman dan sangat nyaman akan dikategorikan $y=1$ (nyaman). (3) Melakukan uji independensi untuk semua variable menggunakan Spearman's rho dengan pertimbangan bahwa variabel respon berupa kategorik. (4) Melakukan estimasi parameter dari variabel respon yang signifikan terhadap masing-masing variabel prediktor. (5) Melakukan uji kesesuaian hasil perhitungan dengan data hasil wawancara.

\section{HASIL DAN PEMBAHASAN}

\section{Profil Pengunjung}

Profil data pengunjung, meliputi jenis kelamin, usia, dan tingkat pendidikan, pada tiap lokasi disajikan pada Gambar 1a. Pengunjung di setiap lokasi lebih didominasi oleh perempuan (56.6\% Ecopark, 70.1\% KRB dan 53.8\% KRC) dibandingkan laki-laki (43.4\% Ecopark, 29.9\% KRB dan 46.2\% KRC). Sebagian besar pengunjung Ecopark adalah orang dewasa antara umur 17-30 tahun (47.9\%), dan 31-50 tahun (46.6\%) sementara di kawasan KRB dan KRC mayoritas antara umur 17-30 tahun masing-masing $71.1 \%$ dan $73.4 \%$. Pengunjung dengan pendidikan SMA atau sederajat lebih mendominasi (48.4\% Ecopark, 65.8\% KRB dan $59.3 \% \mathrm{KRC}$ ) dan selanjutnya diikuti oleh pengunjung yang berpendidikan sarjana (39.3\% Ecopark, 15.8\% KRB dan $16.9 \% \mathrm{KRC})$.

\section{Cuaca dan Kenyamanan Berwisata}

Pengetahuan pengunjung mengenai istilah parameter cuaca, meliputi suhu udara, kelembaban udara, angin, dan radiasi sinar matahari, diuji dengan pertanyaan tertutup. Berdasarkan hasil wawancara, sebagian besar pengunjung mengaku tahu dengan istilah beberapa parameter cuaca tersebut (Gambar 1b). Untuk istilah suhu (88.6\% Ecopark, 82\% KRB dan 76.6\% KRC), kelembaban udara (81.7\% Ecopark, 54.2\% KRB dan 58.6\% KRC), angin (95.0\% Ecopark, 87.3\% KRB dan 92.1\% KRC) dan sinar matahari (88.6\% Ecopark, 61.3\% KRB dan 57.6\% KRC). Namun ketika pengunjung ditanya mengenai istilah kenyamanan termal, sebagian besar mereka menjawab tidak tahu (70.8\% Ecopark, 88.7\% KRB dan 93.1\%).

Untuk mendapatkan informasi mengenai cuaca yang berpengaruh terhadap kenyamanan selama berwisata, kepada pengunjung ditanya mengenai pertimbangan faktor cuaca dalam keputusan mereka melakukan kegiatan wisata. Di ketiga lokasi wisata terlihat pengunjung menilai cuaca sangat berpengaruh terhadap kenyamanan berwisata di masing-masing lokasi $(98.2 \%$ di Ecopark, 98.6\% di KRB dan 97.6\% di KRC, lihat Gambar 1c). Namun ketika parameter cuaca ditanyakan satu per satu dalam mempertimbangkan 
mengunjungi lokasi wisata atau dalam hal pemilihan pakaian, hasilnya sangat bervariasi (Gambar 1d). Untuk kawasan Ecopark mayoritas yang dipertimbangkan pengunjung adalah suhu dan sinar matahari (57.3\% dan 59.5\%). Untuk kawasan KRB mayoritas pengunjung (51.8\%) tidak mempertimbangkan keempat faktor cuaca. Sementara di kawasan KRC pengunjung hanya mempertimbangkan faktor suhu yakni sebesar $60.3 \%$. Selanjutnya kepada pengunjung ditanyakan mengenai pakaian yang mereka pakai ke kawasan wisata apakah sudah mempertimbangkan faktor cuaca (Gambar 1e). Untuk kawasan Ecopark mayoritas pengunjung mempertimbangkan keempat faktor cuaca tersebut (suhu $61.4 \%$, kelembaban udara $53.2 \%$, angin $55.9 \%$ dan sinar matahari 58.2\%). Sebaliknya di kawasan KRB mayoritas pengunjung tidak mempertimbangkan semua faktor cuaca yang ditanyakan yakni sebesar $56.0 \%$. Sementara di kawasan KRC hanya suhu yang dipertimbangkan yakni sebesar $57.6 \%$.
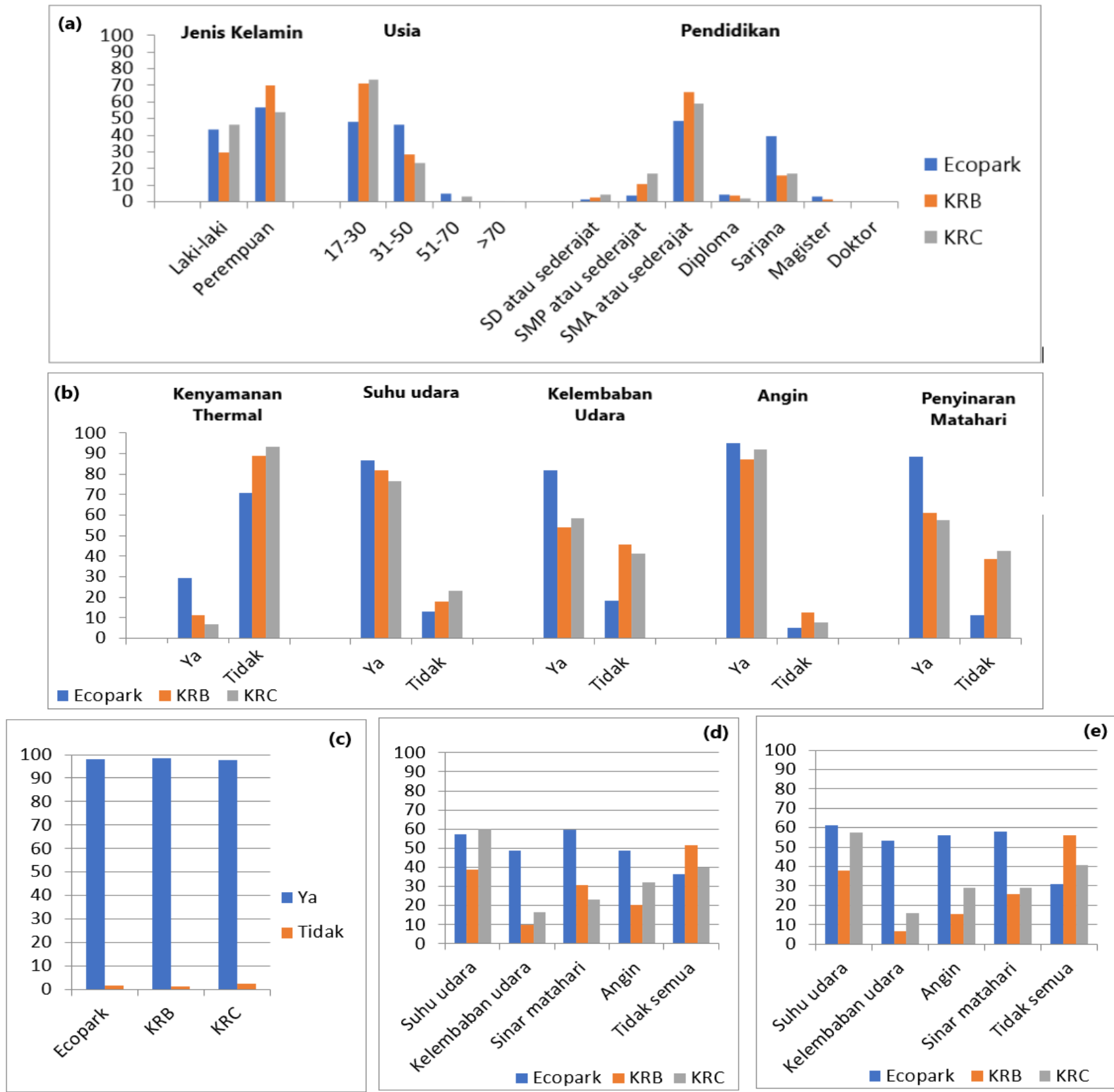

Gambar 1. Hasil analisis berupa persentase dari data pengunjung di tiga lokasi wisata (1) Ecopark, (2) Kebun Raya Bogor (KRB), dan (3) Kebun Raya Cibodas (KRC) untuk beberapa kategori: (a) profil pengunjung, meliputi jenis kelamin, usia dan Pendidikan, (b) pengetahuan pengunjung terhadap beberapa istilah yang digunakan, meliputi istilah kenyamanan termal, suhu udara, kelembaban udara, dan penyinaran matahari, dan (c) pendapat pengunjung terkait pengaruh kondisi cuaca terhadap kenyamanan iklim saat berkunjung. Pertimbangan kondisi tiap parameter iklim dalam hal: (d) keputusan untuk berkunjung ke lokasi tersebut, dan (e) memilih pakaian yang digunakan. 


\section{Persepsi Tingkat Kenyamanan Pengunjung}

Untuk mendapatkan informasi tentang kisaran persepsi tingkat kenyamanan yang dirasakan pengunjung berdasarkan parameter cuaca seperti suhu udara, kelembaban udara, kecepatan angin dan sinar matahari, pengunjung diberikan pertanyaan tertutup. Kategori jawaban adalah sangat tidak nyaman, tidak nyaman, netral, nyaman dan sangat nyaman. Dari perhitungan indeks kenyamanan menggunakan TCI dan HCI dihasilkan skor seperti Tabel 1.

Perhitungan tingkat kenyamanan berdasarkan hasil survei dilakukan dengan menggunakan metode suksesif interval (MSI). MSI merupakan proses mengubah data ordinal (sangat tidak nyaman, tidak nyaman, netral, nyaman dan sangat nyaman) menjadi interval. Dalam proses statistik diperlukan data kuantitatif, oleh karena itu data kualitatif (data ordinal) harus diubah menjadi kuantitatif (interval). Persentase kenyamanan berdasarkan wawancara dengan pengunjung di ketiga lokasi berada di rentang 53\%$78 \%$. Secara keseluruhan, lokasi KRC memiliki persentase kenyamanan tertinggi (78.4\%), kemudian KRB (60\%) dan Ecopark (57.3\%).

Hasil wawancara dengan pengunjung menunjukkan secara keseluruhan kondisi kenyamanan yang dirasakan oleh pengunjung di Ecopark adalah netral sementara di KRB dan KRC pengunjung merasakan nyaman (Tabel 1). Berdasarkan perhitungan skor kenyamanan dengan menggunakan TCI dan HCI serta memodifikasi aspek termalnya, maka diperolah skor yang mendekati hasil survei adalah: untuk kawasan Ecopark adalah indeks TCI yang dimodifikasi termalnya dengan PET Tianjin, KRB adalah HCI tanpa modifikasi aspek termal dan KRC adalah $\mathrm{HCI}$ yang dimodifikasi aspek termalnya dengan PET Tianjin.
Iklim yang dikategorikan nyaman adalah skor TCI dan $\mathrm{HCI} \geq 60$, netral atau dapat ditoleransi rentang skor 40-59 dan yang tidak nyaman skor di bawah 40 (Scott et al., 2016). Ecopark dan KRB memiliki tingkat kenyamanan kategori nyaman pada musim kemarau sedangkan KRC memiliki tingkat kenyamanan kategori nyaman sepanjang tahun (Sudiar et al., 2019).

\section{Perbedaan Persepsi Kenyamanan Pengunjung}

Untuk mendapatkan informasi mengenai perbedaan persepsi pengunjung tentang kenyamanan iklim terhadap pariwisata, dilakukan analisis statistik dengan model regresi logistik biner. Secara umum, model regresi logistik biner sangat cocok untuk menguji hipotesis tentang hubungan antara variabel respon dan variabel prediktor. Variabel respon $(y)$ bersifat biner atau dikotomus dan variabel prediktor $(x)$ yang bersifat polikotomus.

Berdasarkan hasil statistik deskriptif maka variabel prediktor (usia dan pendidikan) dibedakan masing-masing menjadi 3 kategori. Usia dibedakan menjadi: rentang 17-30 tahun, 31-50 tahun dan $>50$ tahun. Tingkat pendidikan dibedakan menjadi: SD-SMA Diploma \& Sarjana dan Pascasarjana.

Uji independensi dengan Spearman's rho pada alpha 5\% dilakukan untuk mengetahui ada tidaknya hubungan antara variabel respon dan prediktor. Hipotesis yang digunakan adalah:

$\mathrm{H}_{0}=$ tidak ada hubunngan antara $\mathrm{y}$ dan $\mathrm{x}$.

$\mathrm{H}_{1}=$ ada hubungan anatara $\mathrm{y}$ dan $\mathrm{x}$.

Tolak $\mathrm{H}_{0}$ jika signifikansi $<\alpha=0.05$.

Uji independensi dari masing-masing lokasi diperoleh hasil hubungan yang nyata antara variabel respon dan prediktor sebagai berikut:

a) Ecopark, hanya suhu (y) dan usia2 ( $x$ ) yang memiliki hubungan nyata.

Tabel 1. Nilai Tourism Climate Index (TCI), Holiday Climate Index (HCI), dan persentase kenyamanan pengunjung pada lokasi Ecopark-Ancol, Kebun Raya Bogor (KRB), Kebun Raya Cibodas (KRC) dengan modifikasi termal Physiological Equivalent Temperature (PET) dan Universal Thermal Climate Index (UTCI).

\begin{tabular}{|c|c|c|c|c|c|c|c|c|c|}
\hline \multirow{3}{*}{ Modifikasi termal } & \multicolumn{3}{|c|}{ Ecopark } & \multicolumn{3}{|c|}{ KRB } & \multicolumn{3}{|c|}{$\mathrm{KRC}$} \\
\hline & & & Kenyamanan & & & Kenyamanan & & & Kenyamanan \\
\hline & $\mathrm{TCl}$ & $\mathrm{HCl}$ & $\begin{array}{l}\text { Pengunjung } \\
\text { (\%) }\end{array}$ & $\mathrm{TCl}$ & $\mathrm{HCl}$ & $\begin{array}{l}\text { Pengunjung } \\
\text { (\%) }\end{array}$ & $\mathrm{TCl}$ & $\mathrm{HCl}$ & $\begin{array}{c}\text { Pengunjung } \\
\text { (\%) }\end{array}$ \\
\hline Tanpa modifikasi & 79.0 & 84.0 & \multirow{8}{*}{57.3} & 54.0 & 59.0 & \multirow{8}{*}{60.0} & 75.0 & 84.0 & \multirow{8}{*}{78.4} \\
\hline PET Eropa & 69.6 & 74.4 & & 37.4 & 43.0 & & 67.4 & 76.0 & \\
\hline PET Taiwan & 84.6 & 85.2 & & 63.6 & 68.6 & & 75.0 & 85.6 & \\
\hline PET Tianjin & 57.2 & 66.6 & & 36.2 & 43.8 & & 69.6 & 77.6 & \\
\hline PET Tel Aviv & 70.4 & 75.0 & & 49.4 & 55.0 & & 69.0 & 77.6 & \\
\hline UTCI Mediterania & 51.0 & 63.0 & & 24.0 & 39.0 & & 64.0 & 72.0 & \\
\hline UTCI Tianjin & 67.0 & 75.0 & & 46.0 & 55.0 & & 72.0 & 80.0 & \\
\hline UTCI Original & 67.0 & 75.0 & & 44.0 & 55.0 & & 72.0 & 80.0 & \\
\hline Kategori* & & & Netral & & & Nyaman & & & Nyaman \\
\hline
\end{tabular}

*kelas: 0-19 Sanqat tidak nyaman; 20-39 Tidak nyaman; 40-59 Netral; 60-79 Nyaman; 80-100 Sanqat nyaman. 
b) KRB, semua variabel respon memiliki hubungan dengan variabel prediktor yakni suhu dan jenis kelamin, suhu dan Pendidikan (pend. 1), kelembaban dan jenis kelamin, kelembaban dan pend. 1, angin dan pend. 1, sinar matahari dan jenis kelamin, keseluruhan dan jenis kelamin, keseluruhan dan pend. 1.

c) KRC, hanya dua variabel respon yang ada hubungan yang nyata, yakni suhu dan keseluruhan terhadap usia2.

Tabel 2 menampilkan hasil regresi logistik biner di ketiga lokasi wisata. Persamaan regresi log biner untuk Ecopark disajikan pada Persamaan (4).

$$
\text { Suhu }=\frac{\exp (0.279-1.658 \text { usia } 2)}{1+\exp (0.279-1.658 \text { usia } 2)}
$$

dengan ketepatan model $56,6 \%$. Pengunjung dengan usia diatas 50 tahun berpeluang merasakan suhu lebih nyaman sebesar $19,1 \%(\operatorname{Exp}(B))$ dibandingkan usia 1730 tahun atau 31-50 tahun. Suhu rata-rata selama survei di kawasan EPA adalah $32,5^{\circ} \mathrm{C}$. Sensitivitas termal menurun secara bertahap seiring bertambah usia (Del Ferraro et al., 2015; Inoue et al., 2016). Sehingga orang yang lebih tua merasa lebih nyaman dibanding usia yang lebih muda pada kondisi lingkungan yang lebih hangat.

Persamaan regresi log biner untuk lokasi KRB disajikan pada Persamaan (5-9).
Suhu $=\frac{\exp (1.716-1.461 \text { Jenis kelamin }-0.906 \text { pend } 1)}{1+\exp (1.716-1.461 \text { jenis kelamin }-0.906 \text { pend } 1)}(5)$

Untuk persamaan suhu udara, ketepatan model $67,6 \%$. Pengunjung perempuan berpeluang merasakan suhu lebih nyaman sebesar $23,2 \%$ dibanding laki-laki dan yang berpendidikan diploma dan sarjana berpeluang merasakan suhu lebih nyaman sebesar 247,4\% dibandingkan pendidikan SD-SMA atau Pascasarjana. Pada suhu yang lebih hangat ternyata perempuan merasa lebih nyaman dibandingkan laki-laki. Hasil ini bersesuaian dengan penelitian Xiong et al. (2015) yang menyatakan bahwa perempuan cenderung lebih menunjukkan ketidakpuasan termal terhadap lingkungan dingin, sementara laki-laki lebih cenderung merasakan ketidaknyamanan termal di lingkungan yang hangat.

$$
\text { Kelembaban }=\frac{\exp (0.49-0.738 \text { jenis kelamin })}{1+\exp (0.49-0.738 \text { jenis kelamin })}
$$

Untuk persamaan kelembaban udara, ketepatan model $58,1 \%$. Pengunjung perempuan berpeluang merasakan kelembaban lebih nyaman sebesar $47,8 \%$ dibandingkan pengunjung laki-laki. Kelembaban rata-rata selama survei adalah $60 \%$. Perempuan pada kondisi udara yang lembab merasa lebih nyaman dibandingkan lakilaki.

$$
\text { Angin }=\frac{\exp (1.43-1.124 \text { pend } 1)}{1+\exp (1.43-1.124 \text { pend } 1)}
$$

\begin{tabular}{|c|c|c|c|c|c|c|}
\hline Lokasi & $\begin{array}{l}\text { Variabel } \\
\text { Respon }\end{array}$ & $\begin{array}{l}\text { Variabel } \\
\text { Prediktor }\end{array}$ & B & $\operatorname{Exp}(B)$ & $\begin{array}{c}\text { Prediksi } \\
\text { model }\end{array}$ & Signifikansi \\
\hline \multirow{2}{*}{ Ecopark } & \multirow{2}{*}{ Suhu } & usia 2 & -1.658 & 0.191 & \multirow[t]{2}{*}{$56.60 \%$} & \multirow[t]{2}{*}{0.041} \\
\hline & & constant & 0.279 & 1.321 & & \\
\hline \multirow{13}{*}{ KRB } & \multirow{3}{*}{ Suhu } & Jenis Kelamin & -1.461 & 0.232 & $67.60 \%$ & 0.000 \\
\hline & & Pend. 1 & 0.906 & 2.474 & & \multirow[t]{2}{*}{0.008} \\
\hline & & constant & 1.716 & 5.56 & & \\
\hline & \multirow{3}{*}{ Kelembaban } & Jenis Kelamin & -0.738 & 0.478 & $58.10 \%$ & \multirow[t]{2}{*}{0.004} \\
\hline & & constant & 0.49 & 1.632 & & \\
\hline & & Pend. 1 & & & & 0.027 \\
\hline & \multirow{2}{*}{ Angin } & Pend. 1 & -1.124 & 0.325 & $76.10 \%$ & \multirow[t]{2}{*}{0.015} \\
\hline & & constant & 1.43 & 4.178 & & \\
\hline & \multirow{2}{*}{ Sinar Matahari } & Jenis Kelamin & -0.789 & 0.454 & $66.90 \%$ & \multirow[t]{2}{*}{0.005} \\
\hline & & constant & 1.187 & 3.278 & & \\
\hline & \multirow{3}{*}{ Keseluruhan } & Jenis Kelamin & -1.176 & 0.309 & $81.30 \%$ & \multirow[t]{2}{*}{0.003} \\
\hline & & constant & 2.222 & 9.229 & & \\
\hline & & Pend. 1 & & & & 0.037 \\
\hline \multirow{4}{*}{$\mathrm{KRC}$} & \multirow{2}{*}{ Suhu } & usia 2 & -1.755 & 0.173 & $91.00 \%$ & \multirow[t]{2}{*}{0.009} \\
\hline & & constant & 2.135 & 8.457 & & \\
\hline & \multirow{2}{*}{ Keseluruhan } & usia 2 & -2.399 & 0.091 & $94.10 \%$ & \multirow[t]{2}{*}{0.000} \\
\hline & & constant & 2.892 & 18.032 & & \\
\hline
\end{tabular}

Tabel 2. Hasil regresi logistik biner dan uji independensi Spearman's rho di Ecopark, Kebun Raya Bogor (KRB), dan Kebun Raya Cibodas (KRC). 
Untuk persamaan angin, ketepatan model sebesar $76,1 \%$. Pengunjung yang berpendidikan diploma dan sarjana berpeluang merasa lebih nyaman (32,5\%) dibandingkan pengunjung yang berpendidikan SDSMA atau Pascasarjana.

$$
\text { Sinar matahari }=\frac{\exp (1.187-0.789 \text { jenis kelamin })}{1+\exp (1.187-0.789 \text { jenis kelamin })}(8)
$$

Untuk persamaan sinar matahari, ketepatan model $66,9 \%$. Pengunjung perempuan berpeluang merasa lebih nyaman $(45,4 \%)$ dibandingkan pengunjung lakilaki. Persepsi pengunjung terhadap sinar matahari sebanyak $68,8 \%$ yang termasuk kategori nyaman. Pada kondisi tersebut perempuan merasa lebih nyaman dibandingkan laki-laki. Hasil ini berlawanan dengan penelitian yang dilakukan Tung et al. (2014), dimana perempuan cenderung menginginkan sinar matahari lebih sedikit dibandingkan laki-laki, meskipun mereka merasa nyaman dengan lingkungan. Namun sikap adaptif yang dilakukan perempuan terhadap sinar matahari yang terik adalah mencari tempat yang teduh. Sangat masuk akal perempuan di kawasan KRB lebih merasa nyaman dibandingkan laki-laki karena kawasan KRB didominasi oleh pohon seluas 54,7 ha dari luas sekitar 77,8 ha yang bisa berfungsi sebagai naungan.

$$
\text { Keseluruhan }=\frac{\exp (2.222-1.176 \text { jenis kelamin })}{1+\exp (2.222-1.176 \text { jenis kelamin })}
$$

Untuk persamaan keseluruhan, ketepatan model 81.3\%. Pengunjung perempuan berpeluang merasakan nyaman secara keseluruhan sebesar 30,9\% dibandingkan pengunjung laki-laki. Suhu kulit perempuan lebih rendah di lingkungan yang dingin dan lebih tinggi di lingkungan yang hangat dibandingkan laki-laki, sehingga laki-laki lebih tidak nyaman terhadap panas daripada perempuan (Viegas, 2017; Xiong et al., 2015). Hal ini dapat menjelaskan kenapa perempuan lebih menyukai kondisi lingkungan yang lebih hangat dibandingkan laki-laki.

Persamaan regresi log biner untuk lokasi KRC disajikan pada Persamaan (10-11).

$$
\text { Suhu }=\frac{\exp (2.135-1.755 \text { usia } 2)}{1+\exp (2.135-1.755 \text { usia } 2)}
$$

Untuk persamaan suhu, ketepatan model 91\%. Pengunjung dengan usia di atas 50 tahun berpeluang merasakan suhu lebih nyaman (17,3\%) dibandingkan pengunjung dengan usia 17-30 tahun atau 31-50 tahun. Suhu rata-rata selama survei di kawasan KRC adalah $24,5^{\circ} \mathrm{C}$. Suhu di KRC lebih rendah dibandingkan EPA dan peluang orang tua merasa lebih nyaman di kawasan KRC juga lebih rendah dibandingkan di kawasan EPA. Namun perbedaan peluangnya tidak terlalu besar $(<2 \%)$.

$$
\text { Keseluruhan }=\frac{\exp (2.892-2.399 \text { usia } 2)}{1+\exp (2.892-2.399 \text { usia })}
$$

Untuk persamaan keseluruhan, ketepatan model 94,1\%. Pengunjung dengan usia di atas 50 tahun berpeluang merasakan nyaman secara keseluruhan sebesar 9,1\% dibandingkan pengunjung dengan usia 17-30 tahun atau 31-50 tahun. Secara keseluruhan persepsi kenyamanan pengunjung di kawasan KRC adalah $78,4 \%$. Orang tua merasa lebih nyaman pada kondisi skor TCI dan HCI ditoleransi.

Setelah melakukan model regresi logistik untuk melihat perbedaan persepsi kenyamanan pengunjung maka langkah selanjutnya adalah melihat pengaruh lokasi (ketinggian tempat) terhadap variabel iklim. Dari hasil perhitungan diperoleh bahwa topografi berpengaruh terhadap semua parameter iklim. Hal ini diidentifikasi dengan nilai signifikansi 0. Akan tetapi, nilai korelasi masing-masing parameter sebagai variable respon terhadap lokasi sebagai variable prediktor sangat lemah (suhu 0.398, kelembaban 0.274, angin 0.213, sinar matahari 0.306, dan keseluruhan 0.335).

\section{KESIMPULAN}

Identifikasi persepsi pengunjung terhadap kenyamanan iklim saat berkunjung ke lokasi wisata berbasis alam dapat dilakukan dengan cara wawancara langsung. Berdasarkan data responden yang diambil secara acak, informasi yang diperoleh antara lain:

1. Pengunjung menilai cuaca berpengaruh terhadap kenyamanan selama berwisata. Di ketiga lokasi wisata Ecopark Ancol, KRB dan KRC berturut-turut $98,2 \%, 98,6 \%$ dan $97,6 \%$.

2. Persepsi dominan terhadap tingkat kenyamanan yang dirasakan pengunjung berdasarkan parameter cuaca di Ecopark Ancol adalah netral (57,3\%), KRB adalah nyaman (60\%) dan KRC adalah nyaman (78,4\%). Nilai perhitungan yang mendekati hasil survei adalah: Ecopark Ancol menggunakan indeks TCI yang dimodifikasi aspek termalnya dengan PET Tianjin (skor 57,2), KRB dengan HCI tanpa modifikasi termal (skor 59) dan KRC dengan HCI yang dimodifikasi aspek termalnya dengan PET Tianjin (skor 77,6).

3. Hasil pengujian yang dilakukan menunjukkan ada perbedaan persepsi kenyamanan oleh pengunjung. Variabel prediktor yang berpengaruh signifikan terhadap variabel iklim adalah jenis kelamin, usia dan tingkat pendidikan. Pada kondisi lingkungan yang lebih hangat orang yang lebih tua dan perempuan merasa lebih nyaman. 
Topografi berpengaruh terhadap semua parameter iklim namun korelasinya tidak kuat.

\section{DAFTAR PUSTAKA}

De Urioste-Stone, S.M., Scaccia, M.D., Howe-Poteet, D., 2015. Exploring visitor perceptions of the influence of climate change on tourism at Acadia National Park, Maine. Journal of Outdoor Recreation and Tourism 11, 34-43. https://doi.org/10.1016/j.jort.2015.07.001

Del Ferraro, S., Iavicoli, S., Russo, S., Molinaro, V., 2015. A field study on thermal comfort in an Italian hospital considering differences in gender and age. Applied Ergonomics 50, 177-184. https://doi.org/10.1016/j.apergo.2015.03.014

Di Napoli, C., Pappenberger, F., Cloke, H.L., 2018. Assessing heat-related health risk in Europe via the Universal Thermal Climate Index (UTCI). International Journal of Biometeorology 62, 1155-1165. https://doi.org/10.1007/s00484018-1518-2

Fang, Y., Yin, J., 2015. National Assessment of Climate Resources for Tourism Seasonality in China Using the Tourism Climate Index. Atmosphere 6. https://doi.org/10.3390/atmos6020183

Gilani, S.I. ul H., Khan, M.H., Pao, W., 2015. Thermal Comfort Analysis of PMV Model Prediction in Air Conditioned and Naturally Ventilated Buildings. Energy Procedia 75, 1373-1379. https://doi.org/10.1016/j.egypro.2015.07.218

Haryadi, A., Kusratmoko, E., Karsidi, A., 2019. Climate Comfort Analysis for Tourism in Samosir District. E3S Web of Conferences 94. https://doi.org/10.1051/e3sconf/20199405001

Inoue, Y., Gerrett, N., Ichinose-Kuwahara, T., Umino, Y., Kiuchi, S., Amano, T., Ueda, H., Havenith, G., Kondo, N., 2016. Sex differences in age-related changes on peripheral warm and cold innocuous thermal sensitivity. Physiology \& Behavior 164, 86-92. https://doi.org/10.1016/j.physbeh.2016.05.045

Lai, D., Guo, D., Hou, Y., Lin, C., Chen, Q., 2014. Studies of outdoor thermal comfort in northern China. Building and Environment 77, 110-118. https://doi.org/10.1016/j.buildenv.2014.03.026

Lai, P.-C., Choi, C.C.Y., Wong, P.P.Y., Thach, T.-Q., Wong, M.S., Cheng, W., Krämer, A., Wong, C.-M., 2016. Spatial analytical methods for deriving a historical map of physiological equivalent temperature of Hong Kong. Building and Environment 99, 22-28. https://doi.org/10.1016/j.buildenv.2015.12.022

Li, H., Song, H., Li, L., 2016. A Dynamic Panel Data Analysis of Climate and Tourism Demand:
Additional Evidence. Journal of Travel Research 56 , 158-171. https://doi.org/10.1177/0047287515626304

Mieczkowski, Z., 1985. The Tourism Climatic Index A Method of Evaluating World Climates for Tourism. The Canadian Geographer / Le Géographe canadien 29, 220-233. https://doi.org/10.1111/j.15410064.1985.tb00365.x

Nazarian, N., Fan, J., Sin, T., Norford, L., Kleissl, J., 2017. Predicting outdoor thermal comfort in urban environments: A 3D numerical model for standard effective temperature. Urban Climate 20, 251-267. https://doi.org/10.1016/j.uclim.2017.04.011

Noome, K., Fitchett, J.M., 2019. An assessment of the climatic suitability of Afriski Mountain Resort for outdoor tourism using the Tourism Climate Index (TCI). Journal of Mountain Science 16, 2453-2469. https://doi.org/10.1007/s11629019-5725-z

Noor, A.B.S., Rakhmat, D.I., Khasanah, S.N., Kurniawan, W., 2018. Pemanfaatan Informasi Holiday Climate Index (HCI) Dalam Sektor Pariwisata (Studi Kasus: Kota Banjarmasin). Prosiding: Seminar Nasional Riset Terapan 3.

Priego, F.J., Rosselló, J., Santana-Gallego, M., 2015. The impact of climate change on domestic tourism: a gravity model for Spain. Regional Environmental Change 15, 291-300. https://doi.org/10.1007/s10113-014-0645-5

Roshan, G., Yousefi, R., Fitchett, J.M., 2016. Long-term trends in tourism climate index scores for 40 stations across Iran: the role of climate change and influence on tourism sustainability. International Journal of Biometeorology 60, 33-52. https://doi.org/10.1007/s00484-0151003-0

Rutty, M., Scott, D., 2016. Comparison of Climate Preferences for Domestic and International Beach Holidays: A Case Study of Canadian Travelers. Atmosphere 7. https://doi.org/10.3390/atmos7020030

Scott, D., Hall, C.M., Gössling, S., 2019. Global tourism vulnerability to climate change. Annals of Tourism Research 77, 49-61. https://doi.org/10.1016/j.annals.2019.05.007

Scott, D., Rutty, M., Amelung, B., Tang, M., 2016. An Inter-Comparison of the Holiday Climate Index $(\mathrm{HCI})$ and the Tourism Climate Index (TCI) in Europe. Atmosphere 7. https://doi.org/10.3390/atmos7060080

Sudiar, N., Koesmaryono, Y., Perdinan, P., Arifin, H., 2019. Karakteristik dan Kenyamanan Iklim Lokasi 
Wisata Berbasis Alam di Eco-Park Ancol, Kebun Raya Bogor dan Kebun Raya Cibodas. EnviroScienteae 15, 240. https://doi.org/10.20527/es.v15i2.6967

Tung, C.-H., Chen, C.-P., Tsai, K.-T., Kántor, N., Hwang, R.-L., Matzarakis, A., Lin, T.-P., 2014. Outdoor thermal comfort characteristics in the hot and humid region from a gender perspective. International Journal of Biometeorology 58 , 1927-1939. https://doi.org/10.1007/s00484014-0795-7
Viegas, R., 2017. Evaluation of thermal comfort of men and women in food courts. International Journal of Science and Engineering Investigations http://www.ijsei.com/papers/ijsei-66517.

Xiong, J., Lian, Z., Zhou, X., You, J., Lin, Y., 2015. Investigation of gender difference in human response to temperature step changes. Physiology \& Behavior 151, 426-440. https://doi.org/10.1016/j.physbeh.2015.07.037 